\title{
ESTIMASI PRODUKTIVITAS PRIMER FITOPLANKTON DI KAWASAN HUTAN MANGROVE BATUKARAS PANGANDARAN, PROVINSI JAWA BARAT
}

\author{
Ramdan Nurdiana $^{\mathrm{a} *}$, Tri Dewi Kusumaningrum Pribadi ${ }^{\mathrm{a}}$, Yudi Nurul Ihsan ${ }^{\mathrm{b}}$ \\ ${ }^{a}$ Departmen Biologi Fakultas Matematika dan Ilmu Pengetahuan Alam Universitas Padjadjaran \\ ${ }^{\mathrm{b}}$ Departmen Ilmu Kelautaan Fakultas Perikanan dan Ilmu Kelautan Universitas Padjadjaran \\ Jl. Raya Bandung - Sumedang KM. 21 Jatinangor Kabupaten Sumedang \\ Provinsi Jawa Barat-Indonesia 45363 \\ *Koresponden penulis : tridewi.pribadi@unpad.ac.id
}

\begin{abstract}
Abstrak
Tingkat kesuburan suatu perairan dapat dilihat dari ketersediaan okigen terlarut yang dihasilkan dari proses fotosintesis fitopankton. Produktivitas fitoplankton sangat bergantung pada faktor fisika-kimia yang ada di lingkungan perairan. Hutan mangrove diindikasikan memberikan kontribusi dalam meningkatkan kesuburan perairan melalui pembusukan seresah yang jatuh ke dalam kolom air. Kajian eksplorasi ini bertujuan untuk menentukan tingkat produktivitas perairan dan korelasinya dengan faktor-faktor lingkungan di kawasan hutan mangrove Batukaras Pangandaran Provinsi Jawa Barat. Pengukuran produktivitas perairan yang diukur secara musiman dilakukan selama satu tahun dalam musim hujan dan kemarau. Sampel air diperoleh dari 3 titik sampling yang terbagi menjadi 3 zona (perairan tawar, mangrove, estuari) dengan masing masing 3 kali pengulangan). Pengukuran produktivitas primer dilakukan dengan metode oksigen gelap terang. Secara kontras dapat diketahui bahwa nilai produktivitas perairan tertinggi terdapat pada daerah estuari di kedua musim $\left(>1000 \mathrm{mgC} . \mathrm{m}^{-3}\right)$. Walaupun tidak terdapat korelasi yang signifikan antara produktvitas primer dengan parameter lingkungan, perubahan yang terjadi antara musim memberikan informasi terhadap pengaruh masing-masing parameter.
\end{abstract}

Kata kunci : Batukaras, mangrove, ekologi, habitat, produktivitas primer

\begin{abstract}
The aquatic prosperity level can be seen from the availability of dissolved oxygen produced from phytoplankton photosynthesis process. Phytoplankton productivity is highly dependent on physicalchemical factors in the aquatic environment. Mangrove forests are indicated to contribute in increasing the aquatic fertility through decay of litter that falls into water collumn. This exploratory study conducted to determine the level of water primary productivity of as well as its correlation with environmental factors in Batukaras mangrove forest area, Pangandaran West Java Province. The seasonal variation of planktonic primary productivity was measured during one year in dry and wet seasons. Water samples were taken from 3 plots devided into three zonation (freshwater, magroves, estuari) with 3 duplications each plots. Primary Productivity were measured by light-dark oxygen bottle method.. In contrast, it appears that the most higher primary productivity rate was show in the estuari both of seasons $\left(>1000 \mathrm{mgC} . \mathrm{m}^{-3}\right)$. Despite there was no significant correlation among primary productivity and environmental parameters, the fluctuation in different seasons quite described the influences of those parameters
\end{abstract}

Keywords : Batukaras, mangroves, ecology, habitat, primary productivity

\section{PENDAHULUAN}

Daerah pesisir memiliki peranan
sebagai pengendali ekosistem berpengaruh terha-dap kondisi sosial dan ekonomi masyarakat di sekitar pantai. Hutan mangrove sebagai komu-nitas tumbuhan yang dominan tumbuh di wilayah pesisir merupakan kawasan dengan tingkat produktivitas yang tinggi. Fungsi eko-logi hutan mangrove ini salah satunya sebagai daerah pengontrol keseimbangan material organik melalui laju produktvitas perairan yang diperankan oleh fitoplankton [1];[2]. 
Indonesia memiliki jumlah dan luasan hutan mangrove terbesar di dunia sehingga dapat menjadi salah satu tolok ukur dalam melihat produktivitas perairannya [3].

Daerah hutan mangrove yang banyak difungsikan sebagai objek rekreasi ini memiliki tingkat kerentanan karena gangguan antropogenik yang tinggi baik dari segi struktur ataupun fungsionalnya terhadap lingkungan. Kombinasi dari perubahan iklim global dan tingginya aktivitas antropogenik dalam suatu ekosistem dapat secara langsung mempengaruhi kondisi ekologinya [4].

Fenomena perubahan iklim global secara simultan meningkatkan konsentrasi karbon dioksida $\left(\mathrm{CO}_{2}\right)$ di atmosfer. Dampak fisiologi dan produktivitas fitoplankton terhadap ke-naikan konsentrasi $\mathrm{CO}_{2}$ ini memberikan implikasi yang penting bagi siklus biogeo-kimia di perairan. Tingginya konsentrasi $\mathrm{CO}_{2}$ terutama di kolom perairan memberikan ke-sempatan bagi fitoplankton untuk meningkat-kan laju produktivitas perairannya dalam batas kadar tertentu [5]. Produktivitas perairan yang tinggi di daerah mangrove dapat menun-jang kehidupan organisme lain. Menurut [6] menyebutkan bahwa karakteristik ekosistem mangrove berdasarkan tingkatan trofiknya dapat menjadi sumber nutrien berbagai jenis organisme perairan salah satunya adalah kepiting.

Sebagai sarana assesment tingkat fungsional hutan mangrove dapat dianalisis dengan memerhitungkan laju produktivitas primer oleh fitoplankton dalam satuan waktu. Tingkat produktivitas perairan ini juga dapat menentukan kondisi trofik suatu perairan.
Pengukuran produktivitas perairan dapat diestimasi berdasarkan pola perhitungan foto-sintesis dan respirasinya. Fitoplankton meng-gunakan karbon dioksida sebagai substrat dalam proses fotosintesis. Konsep pompa biologis ini dikenal juga sebagai tingkatan penggunaan karbon dioksida oleh plankton di dalam perairan [7]. Penelitian ini dilakukan sebagai salah satu strategi dalam mengukur tingkat produktivitas primer.

\section{MATERI DAN METODE}

Penelitian dilakukan pada dua musim (hujan dan kemarau) dalam kurun waktu satu tahun yang berlokasi di daerah wisata hutan mangrove Batukaras Kabupaten Pangandaran Provinsi Jawa Barat. Pembagian titik sampling dilihat berdasarkan kondisi kawasan yang terbagi menjadi tiga zona utama yaitu, zona perairan tawar (FC), zona mangrove (MC), dan zona estuari (EC).

Observasi dilakukan secara in situ dengan mengambil sampel air di setiap spot sampling. Pengukuran kandungan oksigen terlarut dilakukan dengan metode titrasi dan analisis produktivitas primer melalui aktivitas respirasi fitoplankton menggunakan metode gelap terang [8]. Data yang diperoleh dianalisis dengan melihat koefisien korelasi antar parameter. Analisis Korelasi Pearson digunakan dengan bantuan software IBM SPSS Statistics ver. 26. Peta lokasi penelitian disajikan pada Gambar 1. 


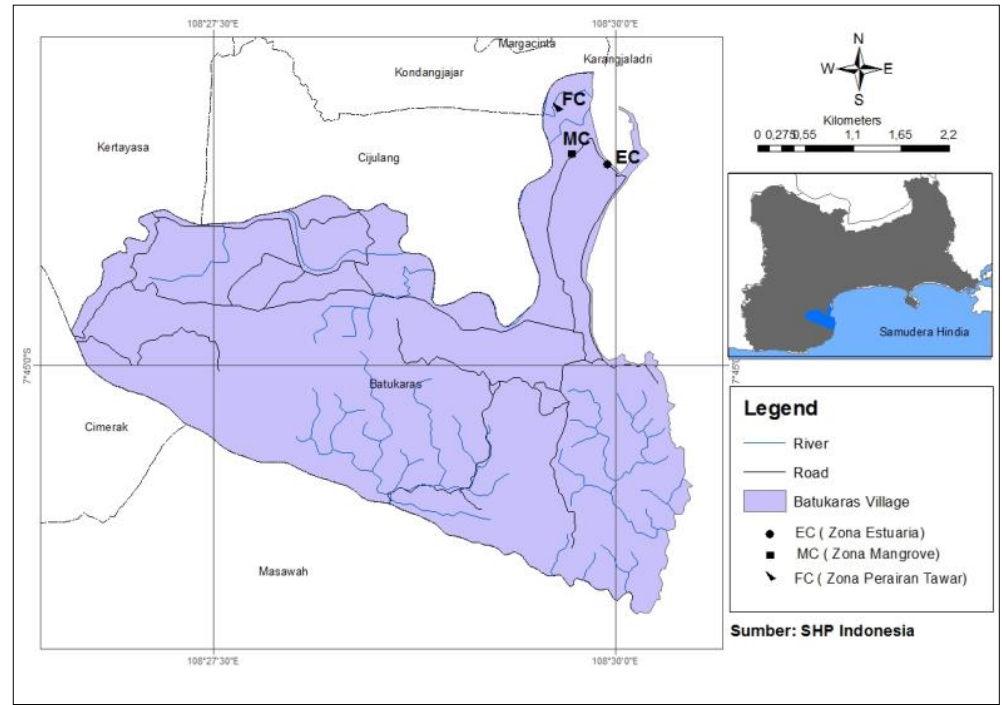

Gambar 1. Peta lokasi penelitian (FC): perairan tawar; (MC): mangrove; dan (EC): estuari

\section{HASIL DAN PEMBAHASAN}

Kawasan hutan mangrove Batukaras secara geografis berada di wilayah pesisir selatan Kabupaten Pangandaran yang berbatasan langsung dengan pantai selatan (Samudera Hindia). Kondisi ini memungkinkan adanya pengaruh langsung terhadap fluktuasi faktor lingkungan yang terjadi di kawasan pesisi dan laut tersebut. Hal ini terlihat dari kondisi pasang surut air laut yang mem- pengaruhi daerah hutan mangrove. Keberadaan hutan mangrove Batukaras ini memberikan peranan penting bagi para nelayan untuk mencari berbagai jenis kepiting bakau dan udang yang bernilai ekonomis [9].

Berdasarkan hasil pengamatan terlihat fluktuasi kandungan oksigen terlarut antar zonasi pada musim yang berbeda. Rata - rata kandungan oksigen tertinggi terjadi pada musim kemarau (DO > $2.00 \mathrm{mg} \cdot \mathrm{L}^{-1}$ ).

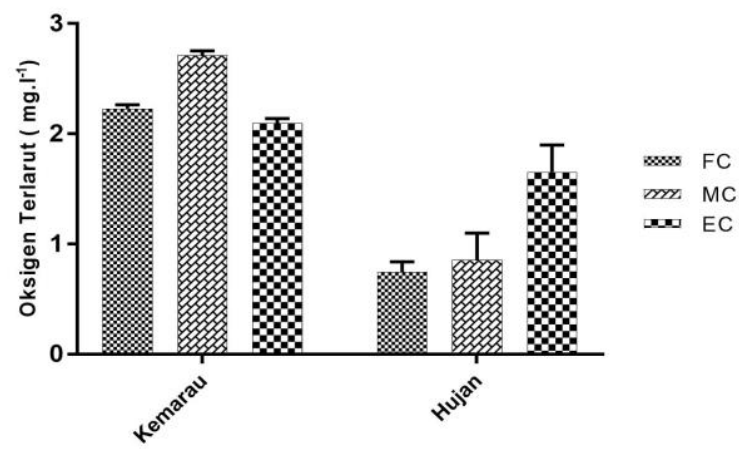

Gambar 2. Kandungan oksigen terlarut di masing-masing zonasi dengan perbandingan musim kemarau dan hujan 


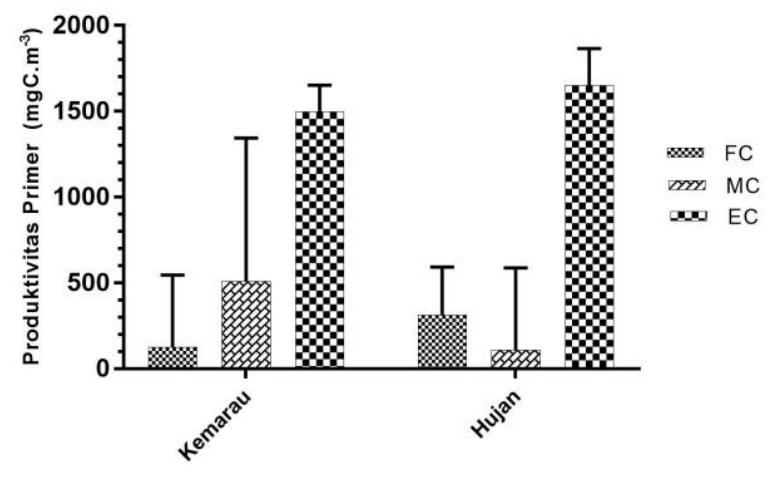

Gambar 3. Kandungan produktivitas primer di masing-masing zonasi dengan perbandingan musim kemarau dan hujan

Tabel 1. Rata - rata parameter lingkungan di stasiun penelitian

\begin{tabular}{cccc}
\hline Parameter & Satuan & Kemarau & Hujan \\
\hline Water Temperature & ${ }^{0} \mathrm{C}$ & $27 \pm 1,1$ & $26,33 \pm 0,57$ \\
Light Intensity & Lux & $6750 \pm 3940,9$ & $5320 \pm 487,54$ \\
Salnity & $\%$ & $25,7 \pm 2,2$ & $36 \pm 4$ \\
$\mathrm{pH}$ & - & $8,0 \pm 0$ & $8,5 \pm 0$ \\
\hline
\end{tabular}

Tabel 2. Koefisien korelasi antar parameter lingkungan

\begin{tabular}{cccccc}
\hline & NPP & Temp & Light & Sal & $\mathrm{pH}$ \\
\hline NPP & 1 & & & & \\
Temp &, 223 & 1 & & & \\
Light &,- 058 &, 468 & 1 & & \\
Sal &, 034 &, 313 & $\mathbf{9 1 4}^{*}$ & 1 & \\
pH &, 015 &, 447 &, $991^{* *}$ &, $955^{* *}$ & 1 \\
\hline
\end{tabular}

*Correlation is significant at the 0.05 level (2-tailed).

Kandungan oksigen terlarut yang paling rendah terjadi di dua zonasi (FC dan $\mathrm{MC}$ ) pada musim hujan dengan kisaran $0-1 \mathrm{mg} . \mathrm{L}^{-}$ ${ }^{1}$. Perbedaan kandungan oksigen terlarut pada setiap musim diindikasikan karena adanya pengaruh kondisi faktor fisika kimia dan nutrien perairan. Hal ini sesuai dengan pernyataan [10] bahwa pertukaran nutrien di perairan berasosiasi dengan kondisi hipoksia dan proses asidifikasi di daerah pesisir laut. Sehingga kondisi ini dapat berpengaruh terhadap aktivitas fotosintesis fitoplankton.

Oksigen terlarut yang merupakan produk sampingan dari fotosintesis memiliki hu-bungan erat dengan nilai produktivitas primer. Kandungan oksigen yang tinggi pada musim kemarau juga diikuti oleh peningkatan rata-rata suhu air dan intensitas cahaya (Tabel 1). Berdasarkan lokasinya, kandungan DO tertinggi terdapat pada zona mangrove (MC) di musim kemarau, dan zona estuari (EC) di musim hujan.

Peningkatan yang terjadi di kedua stasiun ini diindikasikan karena pengaruh pasang surut air laut serta adanya fluktuasi nutrien bagi fitoplankton. Menurut observasi yang dilakukan oleh [4] menyebutkan bahwa va-riasi nutrien dalam jangka panjang di wilayah estuari secara bertahap dipengaruhi oleh wilayah perairan laut di sekitarnya. Hasil 
yang serupa mengenai nilai oksigen terlarut juga diperoleh pada penelitian [11] yang menga-lami peningkatan di musim kemarau (bulan Mei dan Agustus). Peningkatan konsentrasi nutrien sebagai salah satu parameter ling-kungan dalam batas tertentu selalu diikuti dengan peningkatan kelimpahan fitoplankton [12], sehingga diindikasikan laju produktivitas perairannya pun meningkat.

Perubahan kondisi lingkungan termasuk didalamnya kandungan $\mathrm{DO}, \mathrm{pH}$, dan suhu air ini mengendalikan struktur dan komunitas fitoplankton. Menurut [13] peningkatan aliran faktor lingkungan yang tinggi dapat meningkatkan laju produktivitas primer dan aktivitas respirasi organisme didalamnya. Produktivitas primer perairan merupakan hasil aktivitas fotosintesis fitoplankton yang dipengaruhi oleh banyak faktor. Setiap faktor tersebut berpengaruh secara spesifik terhadap jenisjenis fitoplankton.

Hasil analisis produktivitas primer menunjukan perbandingan nilai yang sangat tinggi antar titik sampling (Gambar 3). Zona estuari (EC) memiliki nilai produktivitas primer yang tinggi (> $1000 \mathrm{mgC.m}-3$ ), sedangkan zona mangrove dan perairan tawar memiliki rata-rata produktivitas yang rendah (< 500 mgC.m-3) pada setiap musimnya. Tingginya rendahnya nilai produktivitas primer ini merefleksikan fluktuasi arus dan kondisi lingkungan yang terjadi sehingga berpengaruh pada tingkat aktivitas fitoplankton [14]. Hal ini ditunjukan dari nilai DO pada stasiun estuari yang cenderung tinggi dan konstan di kedua musim (Gambar 2). Hasil yang sama ditunjukan dari penelitian [5] yang menyebutkan bahwa peningkatan suhu dan karbon dioksida di perairan memberikan efek sinergis terhadap produktivitas fitoplankton. Laju produktivitas perairan yang rendah di kawasan hutan mangrove ini dapat diakibatkan karena adanya tekanan hidrobiologis yang tinggi [15].

Perhitungan koefisien korelasi pada setiap parameter lingkungan perairan didominasi oleh hasil korelasi positif antar parameter dengan nilai produktivitas primer (Tabel 2.). Korelasi positif yang signifikan (p $<0.05$ ) terdapat pada parameter intensitas cahaya dengan salinitas. Nilai korelasi negatif juga diperoleh antara produktivitas primer dengan intensitas cahaya. Kondisi ini dimungkinkan terjadi karena nilai intensitas cahaya yang diperoleh saat observasi dilakukan diindi-kasikan terlampau tinggi dari batas-batas normal aktivitas fitoplankton. Kombinasi antar parameter lingkungan menghasilkan implikasi yang berbeda-beda terhadap nilai produktivitas primer perairan pada kondisi tertentu [16].

\section{KESIMPULAN DAN SARAN}

Produktivitas primer fitoplankton di kawasan hutan mangrove memiliki fluktuasi yang tinggi di setiap musimnya. Fluktuasi nilai produktivitas primer pada musim kemarau di ketiga titik sampling berada pada kisaran 300 - $1600 \mathrm{mgC} . \mathrm{m}^{-3}$, sedangkan pada musim hujan berada pada kisaran 100 - 1400 $\mathrm{mgC} . \mathrm{m}^{-3}$. Perbedaan tingkat laju produktivitas primer tersebut diindikasikan karena adanya pengaruh kondisi fisika-kimia perairan pada setiap stasiun dan musimnya.

Sebagai saran dan rekomendasi untuk keberlanjutan penelitian, diperlukan monitoring dan analisis secara periodik dengan pengukuran parameter yang lebih kompleks meliputi nutrien perairan, dan sedimen. Serta analisis aliran energi melalui rantai makanan.

\section{DAFTAR PUSTAKA}

[1] Sigman, D. M. \& Hain, M. P. (2012) The Biological Productivity of the Ocean. Nature Education Knowledge 3(10): 21

[2] Alongi, D. M. (2014). Carbon Cycling and Storage in Mangrove Forests. Annual Review of Marine Science, 6(1), 195219. https://doi.org/10.1146/annurevmarine-010213-135020

[3] Ilman, M., Dargusch, P., Dart, P., \& Onrizal. (2016). A historical analysis of the drivers of loss and degradation of Indonesia's mangroves. Land Use Policy, 54 , 448-459. https://doi.org/10.1016/j.landusepol.2016 .03 .010

[4] Wei, Q., Yao, Q., Wang, B., Wang, H., \& $\mathrm{Yu}, \mathrm{Z}$. (2015). Long-term variation of nutrients in the southern Yellow Sea. 
Continental Shelf Research, 111, 184196.https://doi.org/10.1016/j.csr.2015.08. 003

[5] Zhang, Y., Wang, T., Li, H., Bao, N., Hall-Spencer, J. M., \& Gao, K. (2018). Rising levels of temperature and $\mathrm{CO} 2$ antagonistically affect phytoplankton primary productivity in the South China Sea. Marine Environmental Research, 141(July), 159-166. https://doi.org/10.1016/j.marenvres.2018. 08.011

[6] David, F., Marchand, C., Thành-Nho, N., Truong Van, V., Taillardat, P., \& Meziane, T. (2019). Trophic relationships and basal resource utilisation in the Can Gio Mangrove Biosphere Reserve (Southern Vietnam). Journal of Sea Research, 145(May 2018), 35-43. https://doi.org/10.1016/j.seares.2018.12.0 06

[7] Tao, Y., \& Liu, D. (2019). Trophic status affects the distribution of polycyclic aromatic hydrocarbons in the water columns, surface sediments, and plankton of twenty Chinese lakes. Environmental Pollution, 252, 666-674. https://doi.org/10.1016/j.envpol.2019.05. 139

[8] Wetzel, R.G. dan Likens, G.E. 2000. Limnological Analyses. 3nd. SpringerVerlag. New York.

[9] Kusiani H., \& Sukamto. (2015). Teknik pengamatan vegetasi mangrove di pesisir. 83-90.

[10] Cai, W. J., Hu, X., Huang, W. J., Murrell, M. C., Lehrter, J. C., Lohrenz, S. E., ... Gong, G. C. (2011). Acidification of subsurface coastal waters enhanced by eutrophication. Nature Geoscience, 4(11), 766-770. https://doi.org/10.1038/ngeo1297

[11] Taylor, P., Dalu, T., Clegg, B., Nhiwatiwa, T., Dalu, T., Clegg, B., \& Nhiwatiwa, T. (n.d.). Transactions of the
Royal Society of South Africa Temporal variation of the plankton communities in a small tropical reservoir (Malilangwe, Zimbabwe) Temporal variation of the plankton communities in a small tropical reservoir ( Malilangwe, Zimbabwe ). (February 2013), 37-41. https://doi.org/10.1080/0035919X.2013.7 66280

[12] He, X., Bai, Y., Pan, D., Chen, C. T. A., Cheng, Q., Wang, D., \& Gong, F. (2013). Satellite views of the seasonal and interannual variability of phytoplankton blooms in the eastern China seas over the past 14 yr (1998\&ndash;2011). Biogeosciences, 10(7), 4721-4739. https://doi.org/10.5194/bg-10-4721-2013

[13] Gallardo, B., Español, C., \& Comin, F. A. (2012). Aquatic metabolism shortterm response to the flood pulse in a Mediterranean floodplain. Hydrobiologia, 693(1), 251-264. https://doi.org/10.1007/s10750-0121126-9

[14] Huang, W., Liu, X., Peng, W., Wu, L., Yano, S., Zhang, J., \& Zhao, F. (2018). Periphyton and ecosystem metabolism as indicators of river ecosystem response to environmental flow restoration in a flowreduced river. Ecological Indicators, 92(June), 394-401. https://doi.org/10.1016/j.ecolind.2017.11. 025

[15] Rivera-Monroy, V. H., Danielson, T. M., Castañeda-Moya, E., Marx, B. D., Travieso, R., Zhao, X., ... Farfan, L. M. (2019). Long-term demography and stem productivity of Everglades mangrove forests (Florida, USA): Resistance to hurricane disturbance. Forest Ecology and Management, 440(February), 79-91. https://doi.org/10.1016/j.foreco.2019.02. 036

[16] Hoppe, C. J. M., Klaas, C., Ossebaar, S., Soppa, M. A., Cheah, W., Laglera, L. M., ... Trimborn, S. (2017). Controls of primary production in two phytoplankton blooms in the Antarctic Circumpolar 
Current. Deep-Sea Research Part II:

Topical Studies in Oceanography, 138,

63-73.

https://doi.org/10.1016/j.dsr2.2015.10.00

5 